\title{
A MAGYAR KISVÁLLALKOZÁSOK TIPIZÁLÁSÁNAK LEHETŐSÉGEI AZ ELMÚLT ÉVTIZED HAZAI KUTATÁSAINAK TÜKRÉBEN
}

A kis- és közepes méretú vállalkozások világszerte nagyon színes képet mutatnak, többnyire a kereskedelemben, a szolgáltató szektorban múködnek, de jelentốs a szerepük a mezógazdaságban is. Számos tanulmány születik világszerte a vállalkozásokról, azok piaci szerepéról, típusairól. Többnyire a statisztikák megelégszenek a méret, tevékenység, foglalkoztatás, adófizetés, jogi forma, régió vagy település szerinti tipizálással, de a kutatók számos egyéb szempontot figyelembe véve vizsgálják a kkv-szektort. E tanulmány célja összefoglalni az elmúlt másfél évtized hazai vállalkozás kutatásainak fóbb csoportképzố ismérveit és elemzési szempontjait.

Kulcsszavak: vállalkozás, vállalkozáskutatás, vállalkozások tipizálási ismérvei

Általánosan elfogadott az a tény, hogy a világ gazdaságának meghatározó, domináns szereplői a nemzetközi nagyvállalatok. Mégis az elmúlt évtizedekben a gazdaságban egyre nagyobb szerepet töltenek be a kis- és közepes vállalkozások. Gazdasági szerepük és helyzetük vizsgálata népszerú kutatási területnek tekinthetô. A vállalatok méret szerinti besorolása nem újdonság, azonban megállapítható, hogy az 1980-as évektól egyre erősebb igény és törekvés mutatkozik arra a világgazdaságban, hogy jogszabályba foglaltan, pontosan definiálják, az egyes gazdasági szereplók számára is egyértelmúvé tegyék, mely vállalatok tekinthetók kis vagy közepes méretú vállalkozásnak.

A tipizálás során figyelembe vett tényezốket két csoportra oszthatjuk. Számunkra, az Európai Unió tagországaként, az uniós egységes szabályozás az ismert és elfogadott, amely a kvantitatív tényezóket alkalmazza, míg megvizsgálva más országok gyakorlatát számos kvalitatív tényezôvel találkozunk a definíciókban.

Fontos kiemelni, hogy a termelékenység és a méretgazdaságosság pontos számításokkal meghatározható egy-egy konkrét vállalkozás esetében, azonban jogszabályban általános feltételként egyetlen érték nem adható meg, hiszen ahány vállalkozás, annyiféle érték felel meg például a méretgazdaságossági kritériumnak. Ezért a Japánban használt minősítési ismérvet elfogadva a termelékenység és a méretgazdaságosság fogalmánál hangsúlyozni kell, hogy e mutatók értékét jogszabályban meghatározni nem lehet, csak mint minőségi tényezốt lehet definiálni (Lukács, 2005) (1. táblázat).

1. táblázat

A vállalatok méret szerinti besorolásakor figyelembe vehetố tényezók

\begin{tabular}{|l|l|}
\hline \multicolumn{1}{|c|}{$\begin{array}{c}\text { Kvalitatív } \\
\text { tényezók }\end{array}$} & \multicolumn{1}{c|}{\begin{tabular}{c}
\multicolumn{1}{c|}{ Kvantitatív } \\
tényezók
\end{tabular}} \\
\hline - tevékenység & - saját tóke \\
- tulajdonosi szerkezet & - alkalmazotti létszám \\
- szervezeti felépítési forma & - éves árbevétel \\
- jogi forma & - mérlegfóösszeg \\
- termékszerkezet & - tárgyi eszközök értéke \\
- piaci kapcsolatok & - életkor (az alapítástól eltelt \\
- termelékenység & évek száma) \\
- méretgazdaságosság & \\
\hline
\end{tabular}

Forrás: saját szerkesztés, 2012

\section{VEZETÉSTUDOMÁNY}




\section{Az európai uniós és a magyar kkv-szektor összehasonlítása}

Az Európai Unióban széles körben elismert a kisvállalkozások társadalmi és gazdasági jelentősége. A közösségi KKV-fejlesztési politika a nyolcvanas évek közepén alapvetốen a belső piac kiterjesztése mellett, annak a kisvállalkozásokra gyakorolt hátrányos hatásainak a csökkentésére indult fejlődésnek. Az Európai Bizottság megállapítása szerint a kis- és közepes vállalkozások döntô szerepet játszanak az új munkahelyek teremtésében és a gazdasági növekedésben. Az új üzleti elgondolások kidolgozásával, a piaci rések feltárásával, az innovációval és az új technológiák előnyös felhasználásával kapcsolatos képességük biztosítja a jövốbeli versenyképességet. Napjainkban is meghatározó gazdaságpolitikai cél a KKV-szektor versenyképességének erósítése. Számos program született az EU FP 7 keretprogram keretében, a 2007-2013 tervezési idôszakban, jelentôs támogatási forrásokkal. Ilyen támogatási programok a Versenyképességi és innovációs keretprogram (CIP), az EUREKA, mely a piacorientált kutatási és fejlesztési hálózatok fejlesztését, kiépítését túzte célul. Ebbe a sorba tartozik az Eurostars vagy LIFE+ program sôt, a fiatal vállalkozókat támogató ERASMUS is.
A mikro-, kis- és középvállalkozások jelentős szerepet töltenek be az ország és az Európai Unió gazdasági életében egyaránt. Magyarországon az alkalmazottak mintegy $60 \%$-át foglalkoztatják, a bruttó hozzáadott értéknek csaknem 40\%-át állítják elő, és az exportértékesítés közel 20\%-át realizálják. Az EU-ban múködő vállalatok 99,8\%-a a kis- és középvállalatok (kkv) körébe tartozik. E vállalatok foglalkoztatják a munkaerố kétharmadát, és állítják elố a bruttó hazai termék (GDP) valamivel több mint felét. A kis- és közép-, illetve a nagyvállalkozások ágazati súlya eltérô. A nagyvállalkozások között az ipar és az építőipar túlsúlya figyelhetố meg, a kis- és középvállalkozások esetében viszont a szolgáltatásoké (2. táblázat).

Magyarországot mind gazdasági, mind pedig területi szempontból kettôsség jellemzi. Egyfelől a GDP jelentős hányadát a külföldi kézben levő - nagyrészt exportorientált - nemzetközi nagyvállalatok termelik. Másrészt nagyszámú, hazai tulajdonban levố kis- és középvállalkozással találkozhatunk, melyek - habár arányosan több munkavállalót foglalkoztatnak - gazdasági értelemben a GDP-hez viszonylag kismértékben járulnak hozzá. A területi polarizálódás úgyszintén érzékelhető. A kkv-k Magyarországon belüli földrajzi el-

A vállalati szektor teljesítménymutatói Magyarországon és az EU-ban (2010. év)

2. táblázat

\section{A vála ati sektor teljesitménymutati Magyarorsagon es az EU-ban (2010. ev)}

\begin{tabular}{|c|c|c|c|c|c|c|c|c|c|}
\hline & \multicolumn{3}{|c|}{ Vállalkozások száma } & \multicolumn{3}{|c|}{ Foglalkoztatatás } & \multicolumn{3}{|c|}{ Hozzáadott érték } \\
\hline & \multicolumn{2}{|c|}{ Magyarország } & \multirow{2}{*}{$\frac{\text { EU-27 }}{\%}$} & \multicolumn{2}{|c|}{ Magyarország } & \multirow{2}{*}{$\frac{\text { EU-27 }}{\%}$} & \multicolumn{2}{|c|}{ Magyarország } & \multirow{2}{*}{$\frac{\text { EU-27 }}{\%}$} \\
\hline & $\mathrm{db}$ & $\%$ & & fö & $\%$ & & $\operatorname{Mrd} €$ & $\%$ & \\
\hline Mikrovállalkozás & 516092 & 94,23 & 92,10 & 917258 & 35,56 & 29,80 & 8 & 17,80 & 21,60 \\
\hline Kisvállalkozás & 26370 & 4,81 & 6,60 & 500905 & 19,42 & 20,40 & 7 & 15,60 & 18,90 \\
\hline Középvállalkozás & 4432 & 0,81 & 1,10 & 430770 & 16,70 & 16,80 & 9 & 20,00 & 17,90 \\
\hline Kkv-k & 546894 & 99,85 & 99,80 & 1848933 & 71,68 & 67,00 & 24 & 53,30 & 58,40 \\
\hline Nagyvállalkozás & 806 & 0,15 & 0,20 & 730334 & 28,32 & 33,10 & 21 & 46,70 & 41,60 \\
\hline Összesen & 547700 & 100,00 & 100,00 & 2579267 & 100,00 & 100,00 & 45 & 100,00 & 100,00 \\
\hline
\end{tabular}

Forrás: Nemzetgazdasági Minisztérium: A kkv-k helyzete, Magyarok a piacon, forrásteremtés kkv-knak., Heti Válasz Kiadó konferencia 2011.

Regisztrált és múködô vállalkozások Magyarországon és az EU-ban (2008)

\begin{tabular}{|l|c|c|c|}
\hline & $\begin{array}{c}\text { A regisztrált vállalkozások } \\
\text { megoszlása }\end{array}$ & $\begin{array}{c}\text { Magyarország múködő } \\
\text { vállalkozásainak a megoszlása }\end{array}$ & $\begin{array}{c}\text { Az EU-27 múk } \\
\text { vállalkozós }\end{array}$ \\
\hline Nagyvállalkozás & $0,06 \%$ & $0,15 \%$ & $0,20 \%$ \\
\hline Kkv összesen & $99,94 \%$ & $99,85 \%$ & $99,50 \%$ \\
\hline Mikro & $97,48 \%$ & $94,36 \%$ & $91,80 \%$ \\
\hline Kis & $2,14 \%$ & $4,71 \%$ & $6,70 \%$ \\
\hline Közép & $0,32 \%$ & $0,77 \%$ & $1,10 \%$ \\
\hline Összesen & $100,00 \%$ & $100,00 \%$ & $100,00 \%$ \\
\hline
\end{tabular}

Forrás: KSH, 2009 és Eurostat, 2010

VEZETÉSTUDOMÁNY 
helyezkedése meglehetősen egyenlőtlen, erős nyugatkelet diverzifikáció mutatható ki. A nyugati megyékben múködő vállalkozások több tókével rendelkeznek és erősebb a külpiaci orientációjuk a keleti területekéihez viszonyítva. A kkv-szektor jellemzố vonása a vállalkozások koncentrációja a központi régióban, azon belül is Budapest székhellyel, ahol a társaságok aránya sokkal magasabb az egyéni vállalkozások számához képest.

A vállalkozások méret szerinti besorolása alapján a magyar vállalati szektor sajátos struktúrát vesz fel: a túlsúlyos alap és az aránytalanul vékony csúcsosodás jellemzi. Kevés a nagy- és középvállalat, és különösen sok a kezdô, jórészt önfoglalkoztatáson alapuló kényszervállalkozás aránya. Ez a tartós és kiegyensúlyozott fejlődés szempontjából kedvezőtlen. A ténylegesen múködő vállalatok aránya is viszonylag alacsony, a regisztrált szervezeteknek csak 53-55 százaléka folytat rendszeres termeló- illetve szolgáltató tevékenységet (Ecostat, 2008) (3. táblázat).

Magyarországon a kkv-k szignifikáns gazdasági jelentőséggel bírnak. Az összes adó $68 \%$-a, a fizetések $57 \%$-a ebból a szektorból származik. A kkv-k termelték a belföldi értékesítés 63\%-át, a külföldi értékesítés $33 \%$-át, a befektetések 44\%-át realizálva, és a dolgozók $56 \%$-át foglalkoztatva. A reprezentatív gazdasági adatok szerint Magyarországon 1000 fớre 75 múködő kkv jut, míg az EU-ban 48. Ennek ellenére a vállalkozói szféra által termelt GDPból a kkv-szektor részesedése elmarad az EU hasonló adataitól (KSH, 2010).

A közepes vállalkozások jelentôs része nagy multinacionális cégek vagy a feldolgozóipar terjeszkedő exportorientált, külföldi tulajdonú vállalkozásainak kisebb fióktelepei, üzletágai. Vannak magyar tulajdonú dinamikusan fejlődő, új alapítású kisvállalkozások, valamint a privatizáció során a nagy állami vállalatokból kivált vállalkozások. Másrészt vannak magyar tulajdonú, dinamikusan fejlődő, új alapítású kisvállalkozások, valamint a privatizáció során a nagy állami vállalatokból kivált kisvállalkozások is.

Az 1. ábra a vállalkozások néhány fontos mutatójának százalékos megoszlását mutatja, összehasonlítva az Európai Unió vállalkozásainak átlagos adataival. A kkv-k gazdaságban betöltött szerepe változatlanul stabil, és jelentősen befolyásolják a gazdaságok versenyképességét. A vállalkozások száma alapján elmondható, hogy a magyar és az EU-s kkv-szektor közötti különbség csökken, a kis- és középvállalkozói szektoron belül a mikrovállalkozásokból van a legtöbb. A foglalkoztatottak aránya a kkv- és a nagyvállalkozói szektorban is magasabb az EU-27 átlagánál. Ugyanakkor a hozzáadott értékük és a munkatermelékenységük jóval az EU-27 átlag alatt marad. Ennek oka, hogy a munkatermelékenységet az egy alkalmazottra esó hozzáadott értékkel mérjük. Az átlagos vállalatméretet vizsgálva megállapítható, hogy egyedül a kisvállalatok átlagos nagysága haladja meg az EU-s átlagot.

$\mathrm{Az}$ ágazati megoszlást vizsgálva megállapítható, hogy a szolgáltató szektor foglalkoztatja a legtöbb mun-

1. ábra

\section{VEZETÉSTUDOMÁNY}

XLIII. ÉVF. 2012. KÜLÖNSZÁM / ISSN 0133-0179 
A kkv-k a jelenlegi szabályozási és jogi környezetben jelentôs adminisztrációs és fiskális teherrel szembesülnek, ami szintén csökkenti a versenyképességüket. A hazai kkv-k jellemzôje az is, hogy további terjeszkedésük meglehetôsen korlátozott, mivel erre a célra szinte lehetetlen számukra hitelt vagy kölcsönt szerezni. A szektor sajátos jellemzóiból adódóan a tôkeerejük és hitelképességük általában alacsonyabb a nagyobb vállalkozásokéhoz képest.

Riasztó az a tény is, hogy a multinacionális vállalatok a saját, eredeti alvállalkozóikra támaszkodnak, kihasználatlanul hagyva a potenciális magyar kkv-kat. A korábban említett elmaradó pénzügyi kapacitás miatt a kkv-k kevésbé innovatívak, a $\mathrm{K}+\mathrm{F}$ és a technológiai beruházások szintje alacsony. Eszközeik, technológiájuk, az informatikai rendszereik nem elég modernek ahhoz, hogy megfeleljenek a multinacionális cégek igényeinek (Sasvári, 2010). A termelés alacsony minősége szintén hátráltatja a kkv-k országon belüli és nemzetközi hálózatokba való bekapcsolódását. A kkv-szektor jövóbeni növekedése és versenyképessége érdekében elengedhetetlen a vezetői készségek és képesség, a marketing és az üzleti tudás intenzív fejlesztése.

\section{Általános tipizálási ismérvek}

A klasszikus tipizálási ismérvek valamennyi kutatásban használatosak, amelyek az OECD ajánlásában, az Európai Unió egységes szabályozásában, illetve hazánkban a 2004. évi XXXIV. törvényben (a kis- és középvállalkozásokról, fejlődésük támogatásáról) definiáltak. A törvény rendelkezik a mikrovállalkozás, a kisvállalkozás és a középvállalkozás, valamint az önálló és a kapcsolódó vállalkozás fogalmáról.

A méret szerinti csoportosításon túl a jogi forma szerinti elemzések szerepe is meghatározó. Az elsó társasági törvény (1988. évi VI. törvény a gazdasági társaságokról) megjelenése óta csökkent az alapítható vállalkozások jogi formáinak a száma. Sok esetben a jogi személyiségü és a jogi személyiség nélküli kategóriák szerint készülnek az elemzések, mások a statisztikai adatközlésben megjelenó tényleges jogi forma szerint (betéti társaság, korlátolt felelósségú társaság, részvénytársaság, a 2006. évi IV. törvény a gazdasági társaságokról) készítik el elemzéseiket. Természetesen a jogi forma szerinti vizsgálatokból nem maradhatnak ki az egyéni vállalkozások és a szövetkezetek sem.

A vállalkozáskutatások általános szempontjai közé tartozik a vállalkozások tevékenyég szerinti elemzése. Az iparágak fejlődési tendenciái, a foglalkoztatásban betöltött szerepük, a GDP-hez való hozzájárulásuk, a külpiaci aktivitásuk önálló kutatási témák. Valamennyi kutatás első számú adatforrása a KSH adatbázisa, mely adatokat gyújt és szolgáltat a TEÁOR-számok szerint is. A statisztikai nyilvántartás adatokat gyújt regisztrált, múködő és nem múködő́ vállalkozások kategóriájában is.

Az OECD szerinti fố csoportok: megszûnó, túléló és növekvớ vállalkozások. E három kategóriával is számos kutatásban találkozhatunk.

\section{A hazai vállalkozáskutatások eredményei, újabb tipizálási módok}

A rendszerváltást követóen a vállalkozási dinamika elemzése és a jogi formák szerinti összetétel vizsgálata volt a meghatározó. Az 1990-es évek elsố felének gazdasági depresszióját (inflációs csúcs 1995-ben, az államadósság és a munkanélküliségi ráta) követôen egyre nagyobb figyelmet kaptak a vállalkozások mint foglalkoztatók, illetve a privatizáció nyomán kialakult tulajdonosi szerkezeti vizsgálatok. E témakörben készült Czakó (1997) tanulmánya. Vizsgálata során a tulajdonosokat a foglalkoztatotti/tulajdonosi státus szerint három csoportba osztotta. A teljes állásban vállalkozók, akik a vállalkozói szférában dolgoznak főállásban, ső́t kiegészítő foglalkozásuk is vállalkozói tevékenység, a mellékállásban vállalkozók, akiknek van munkaviszonya valamely állami vállalatnál, szövetkezetnél vagy költségvetési, illetve önkormányzati intézménynél, de kiegészítésként vállalkozási tevékenységet is folytatnak. A harmadik csoport a nyugdíj mellett vállalkozók. Ezeken túlmenóen egy speciális csoportot különített el, a többszörös tulajdonosok csoportját, azok a vállalkozók, akik egyszerre több vállalkozásban is tulajdonosok még, ha az elóbbi három kategória valamelyikébe tartoznak is. Ez a csoport majd kiemelt jelentôségú lehet a vállalkozások növekedésében.

Egy addig még nem vizsgált, újszerú vizsgálati szempontot követve Török (1997) a vállalkozások munkamegosztásban betöltött szerepét elemezte. Megállapítása szerint ,az ipari kkv-k olyan munkamegosztási struktúrákban helyezkednek el, amelyek horizontális és vertikális, kompetitív és komplementer elemeket egyaránt tartalmaznak. Ezeken a bonyolult struktúrákon belül nagyon sok ipari kkv helyzete rögzített, és versenykilátásait ez a pozíció gyakran teljesítményénél is jobban befolyásolja." Míg a kiskereskedelem minden egyes piaci résztvevője a fogyasztókért versenyez, addig az iparban a verseny a beszállítókért és alvállalkozókért folyik, s a piaci szereplók csak többszörös áttételen keresztül kapcsolódnak a fogyasztói piacokhoz. A magyar ipar kkv-it a szerzó hat csoportba osztotta, kiemelve azonban, hogy csak ritkán tölthető meg mind a hat csoport valós piaci szereplókkel. „A csoportosítás 
alapelve az, hogy az adott cég mennyire játszik aktív szerepet a fó partnereivel fenntartott tartós munkamegosztási kapcsolataiban. Ez az aktivitási fok összefügg az egyes cégeknél képződött hozzáadott érték arányával a végsố eladási árban. A kapcsolatrendszer jellege függ a kérdéses cég tốkeerejétől, múszaki fejlettségétól, piaci bevezetettségétól, valamint attól, hogy milyen, a piac által is elismert $\mathrm{K}+\mathrm{F}$ potenciállal rendelkezik. A szempontokat figyelembe véve Török a következó hat csoportot definiálta: 1. passzív bérmunkázó cég, 2. aktív bérmunkázó cég, 3. passzív beszállitó cég, 4. aktív beszállitó cég, 5. önálló fejlesztésre képes vállalkozás, 6. a végtermékek piacán önállóan is versenyképes vállalkozás („„önálló” piaci szerepló) (Török, 1997).

Ma már klasszikusnak tekinthetô Vecsenyi (1999) tipizálása, mely a szocialista ipari szerkezet felbomlása után kialakult hazai vállalkozásokat, szervezeteket négy csoportba sorolta: hangya, gazella, tigris és dinoszaurusz. A portfólióelemzés két vizsgálati szempontja az üzleti és múködési tapasztalat, valamint a vállalkozási és változási készség. A statisztikai adatokat vizsgálva megállapítható, hogy hazánkban a mai napig a hagyományos kisvállalkozások - a hangyák - a legnépesebb vállalkozói csoport. A dinamikusan növekvố vállalkozó nagyvállalatok aránya nagyon alacsony, s a válság visszafogta az éppen megerôsödố induló gazellákat, akiket gyors, dinamikus növekedés jellemezhetne. A tigrisek csoportjában többnyire a külföldi tulajdonú, jelentős piaci erôt képviselő vállalatok szerepelnek.

Lengyel (2002) a kkv négy típusát különíti el. A tipizáláskor a regionális gazdaságfejlesztés nézôpontját alkalmazza. Szerinte a kkv-k körébe számos és sokszínú vállalkozás tartozik, melyek az alábbi kategóriákba oszthatók: multinacionális vagy helyi nagyvállalatokhoz kapcsolódó $k k v-k$. Ezek, mint elnevezésükból is kiderül, szorosan kötôdnek egy-egy nagyvállalathoz, azok beszállítói, illetve szolgáltatói körét alkotják. E vállalkozások tehát nagymértékben függnek a nagyvállalattól. Innovatív, fóleg tudásalapú $k k v-k$, amelyek önállóan vagy regionális hálózatba, klaszterbe szervezódve sikeresen részt tudnak venni a globális versenyben, és sikeresen tudják növelni piaci részesedésüket. Helyi, regionális piacon múködố $k k v-k$, ezek fóleg az idegenforgalom és vendéglátás vállalkozói. A helyi lakossági keresletet kielégítő olyan $k k v-k$, amelyek termelékenységüket javítva olcsóbb és jobb minőségú szolgáltatást tudnak nyújtani. Lengyel felhívja a figyelmet arra, hogy minden típusú kkv másmás fejlesztési eszközt, forrást és módozatot igényel.

Nem meglepó, hogy az EU-csatlakozás apropóján, a vállalkozói korszak hajnala után másfél évtizeddel megjelent az elsố Vállalkozások demográfiája címú jelentés (2006), követve az egységes európai módszertant. Ez az 1999 és 2003 közötti időszak statisztikai adatait elemezve határozta meg a hazai vállalkozások négy csoportját: múködó, valódi új vállalkozás, valódi megszünt vállalkozás, túléló vállalkozás. Azóta ezeket a kategóriákat valamennyi kutató használja és hivatkozza.

A vállalkozások gazdasági teljesítményének mérése a statisztikai adatszolgáltatás és az adóbevallások adatainak felhasználásával, elemzésével lehetséges. Idősoros elemzések méret, jogi forma, múködési élettartam, regionális és területi elhelyezkedés alapján, iparágak szerinti bontásban végezhetóek. A GKM 2004. évi országos jelentésében a hazai vállalkozások négy csoportját határozta meg: kiforratlan vállalkozók, életvitel-vállalkozók, növekedésorientált vállalkozók, „hósök”, amelyek szintén növekedésorientáltak, magas kockázatvállalási és bizonytalanságtürő képességgel rendelkeznek.

A piaci kapcsolatok elemzése a kétezres évekre vált népszerú kutatási témává. Nagy (2005) kutatásaiban négy csoportot definiál: multinacionális vagy helyi nagyvállalatokhoz kapcsolódó, innovatív, fóleg tudásalapú, helyi, regionális piacokon múködó, helyi lakosság keresletét kielégító vállalkozások.

Román 2006-os tanulmányában felveti a vállalkozásokról rendelkezésre álló és potenciálisan gyứjthetô és feldolgozható statisztikai adatok problémáját. Az EU-s irányelveknek megfeleló, törvényben meghatározott kategóriák pontos szabályozása már lehetőséget ad arra, hogy definiáljuk, mit értünk a vállalkozás fogalma alatt, és milyen méretnagyságok különböztethetók meg. Azonban semmilyen adat nem áll rendelkezésre a teljesítményekkel, az átalakulásokkal vagy a közös tulajdonosi körhöz való tartozásukkal kapcsolatosan. Ezek hiányában viszont a jelenlegi rendszerünkben nyilvánosságra hozott adatok, statisztikák téves következtetéshez is vezethetnek (Román, 2006a). Vállalkozáskutatásában már hat fontos csoportot különít el a hazai vállalkozások vizsgálata során. Megkülönbözteti a születó; önfoglalkoztató (lehet: fô- és mellékfoglalkozású vállalkozó), „vállalkozó vállalat", életstílus-vállalkozás, növekedésre törekvő vállalkozás, túlélő vállalkozás (Román 2006b).

Bálint (2006) értekezésében a vállalkozások stratégiai céljait vizsgálva 8 csoportot különböztetett meg. Egyre többször merül fel a vállalkozás átadásának, öröklésének a kérdése, hiszen az elsố vállalkozó generáció már a nyugdíjaskorba lép. Kutatásában erre a kérdéskörre is kitért. Az általa megkülönböztetett, elsôsorban tulajdonosi szempontból tipizált vállalkozási, vállalati típusok a következók: multinacionális vállalatok, nemzetközi családi tulajdonú vállalkozások, magyar tulajdonú nagy- és középvállalkozások, magyar tulajdonú mikro- és kisvállalkozások, kényszervállal- 
A hazai kkv-k kutatási tipizálási ismérvei és típusai

\begin{tabular}{|c|c|c|c|}
\hline Kutató neve & Kutatás éve & Tipizálási ismérv & kkv-típusok \\
\hline Czakó Ágnes & 1997 & $\begin{array}{l}\text { - a tulajdonosok } \\
\text { foglalkoztatotti, tulaj- } \\
\text { donosi státusa szerint }\end{array}$ & $\begin{array}{l}\text { - teljes állásban vállalkozók } \\
\text { - mellékállásban vállalkozók } \\
\text { - nyugdíj mellett vállalkozók } \\
\text { - többszörös tulajdonosok }\end{array}$ \\
\hline Török Ádám & 1997 & $\begin{array}{l}\text { - a vállalkozások mun- } \\
\text { kamegosztásban betöl- } \\
\text { tött szerepe alapján }\end{array}$ & $\begin{array}{l}\text { - passzív bérmunkázó cég } \\
\text { - aktív bérmunkázó cég } \\
\text { - passzív beszállító cég } \\
\text { - aktív beszállító cég } \\
\text { - önálló fejlesztésre képes vállalkozás } \\
\text { - a végtermékek piacán önállóan is versenyképes vállalkozás }\end{array}$ \\
\hline Vecsenyi János & 1999 & $\begin{array}{l}\text { - üzleti és múködési } \\
\text { tapasztalat, valamint a } \\
\text { vállalkozási és válto- } \\
\text { zási készség }\end{array}$ & $\begin{array}{l}\text { - hangya } \\
\text { - gazella } \\
\text { - tigris } \\
\text { - dinoszaurusz }\end{array}$ \\
\hline Lengyel Imre & 2002 & $\begin{array}{l}\text { - regionális gazdaság- } \\
\text { fejlesztés }\end{array}$ & $\begin{array}{l}\text { - multinacionális vagy helyi nagyvállalatokhoz kapcsolódó kkv-k } \\
\text { - innovatív, fôleg tudásalapú kkv-k } \\
\text { - helyi, regionális piacon múködő kkv-k } \\
\text { - a helyi lakossági keresletet kielégítô kkv-k }\end{array}$ \\
\hline $\begin{array}{l}\text { A vállalkozások } \\
\text { teljesítménye GKM }\end{array}$ & 2004 & $\begin{array}{l}\text { - gazdasági telje- } \\
\text { sítménymutatók } \\
\text { elemzése }\end{array}$ & $\begin{array}{l}\text { - kiforratlan vállalkozók } \\
\text { - életvitel-vállalkozók } \\
\text { - növekedésorientált vállalkozók } \\
\text { - „hősök” }\end{array}$ \\
\hline $\begin{array}{l}\text { A vállalkozások } \\
\text { demográfiája }\end{array}$ & 2006 & $\begin{array}{l}\text { - egységes európai } \\
\text { módszertannal végzett } \\
\text { életpálya-elemzés }\end{array}$ & $\begin{array}{l}\text { - múködő } \\
\text { - valódi új vállalkozás } \\
\text { - valódi megszúnt vállalkozás } \\
\text { - túlélő vállalkozás }\end{array}$ \\
\hline Román Zoltán & 2006 & $\begin{array}{l}\text { - vállalkozási életpálya } \\
\text { vizsgálata }\end{array}$ & $\begin{array}{l}\text { - születố } \\
\text { - önfoglalkoztató (lehet: fő- és mellékfoglalkozású vállalkozó) } \\
\text { - „vállalkozó vállalat” } \\
\text { - Életstílus-vállalkozás } \\
\text { - növekedésre törekvố vállalkozás } \\
\text { - túlélő vállalkozás }\end{array}$ \\
\hline Bálint András & 2006 & $\begin{array}{l}\text { - tulajdonosi szerkezet } \\
\text { vizsgálata }\end{array}$ & $\begin{array}{l}\text { - multinacionális vállalatok } \\
\text { - nemzetközi családi tulajdonú vállalkozások } \\
\text { - magyar tulajdonú nagy- és középvállalkozások } \\
\text { - magyar tulajdonú mikro- és kisvállalkozások } \\
\text { - kényszervállalkozások } \\
\text { - taktikai vállalkozások } \\
\text { - állami vállalkozások } \\
\text { - önkormányzati vállalkozások }\end{array}$ \\
\hline Palócz Éva & 2010 & $\begin{array}{l}\text { - növekedés módja } \\
\text { szerinti elemzés }\end{array}$ & $\begin{array}{l}\text { - nominálisan csökkenő vállalkozás } \\
\text { - stagnáló } \\
\text { - dinamikus vállalatok } \\
\text { - kiemelkedően növekvő } \\
\text { - rakéták }\end{array}$ \\
\hline
\end{tabular}

kozások, taktikai vállalkozások, állami vállalkozások, önkormányzati vállalkozások.

A világgazdasági válságból és annak negatív makrogazdasági hatásaiból az erôs innovatív vállalkozások piaci térnyerése lehet a megoldás. Ezeknek a gyorsan növekvő kkv-knak a „titkait” kutatva Palócz (2010) öt vállalkozási csoportot különített el, kiemelve, hogy a gazdaságpolitikának a növekedésorientált vállalkozá-

Forrás: saját szerkesztés, 2012

sokra kellene összpontosítania. Megkülönbözteti a nominálisan csökkenó vállalkozás, stagnáló, dinamikus vállalatok, kiemelkedóen növekvó, rakéták csoportját. Ugyanezzel a kérdéskörrel foglalkozik a GKI kutatásvezetôje, mikor a magyar gazellák jellemzőit vizsgálja (Némethné Pál, 2010) (4. táblázat). 
Az elmúlt években mind a hazai, mind pedig a regionális kis- és középvállalkozás-kutatások jelentős fejlődést mutatnak. A vállalkozások szerkezeti jellemzői nem változtak az utóbbi években, így továbbra is a magas munkaeró és alacsony tókeintenzitás jellemzi óket. A foglalkoztatottak mintegy kétharmada a kkv-khoz köthetô, míg az árbevételből és a jövedelemtermelésból való részesedésük a nagyvállalkozásokhoz képest elenyészố. Bár ez a jelenség természetesnek mondható, mértéke jóval meghaladja a fejlett országokban mért különbséget. A vállalkozások elaprózottsága mind regionális, mind országos szinten megfigyelhető, és közös probléma, hogy hiányzik egy erős középmezôny, mely a betelepülő multinacionális cégek beszállítójává válhatna.

Összegzésként megállapítható, hogy számos szempontból vizsgálható az a sokaság, melyet kkv-knak nevezünk. A kutatási témák és irányok egyes esetekben egymásra épülnek, míg mások új megközelítést jelentenek (2. ábra).

\section{Felhasznált irodalom}

Bálint A. (2006): Merre tovább középvállalkozások? - stratégiai lehetôségek a vállalkozásátadás folyamatában. $\mathrm{PhD}$ értekezés. http://phd.lib.uni-corvinus. hu/4/1/balint_andras.pdf

Czakó Á. (1997): Kisvállalkozások a kilencvenes évek elején: Vállalkozások-e a kisvállalkozások? Szociológiai Szemle. No. 3, p. 93-116.

Ecostat (2008): Fenntartható növekedés és a vállalkozási struktúra. Mikroszkóp, XI. évfolyam 2. szám, február

GKM (2004): A vállalkozások teljesítménye. Budapest: GKM

GKM (2007): A kis- és középvállalkozások fejlesztésének stratégiája 2007-2013. Budapest: GKM

Lengyel I. (2002): A regionális gazdaság- és vállalkozásfejlesztés alapvetó szempontjai. in: Buzás N. - Lengyel I. (szerk.): Ipari parkok fejlődési lehetőségei: regionális gazdaságfejlesztés, innovációs folyamatok és klaszterek. Szeged: SZTE GTK, JATE Press

Lukács E. (2005): The economic role of SMEs in the world economy, especially in Europe. in: European Integration Studies, 4 (1), p. 3-12. University of Miskolc www.unimiskolc.hu/uni/res/kozlemenyek/2005/EIS1.doc

Makra Zs. (szerk.) (2007): A technológiaorientált kisvállalkozások jellegzetességei és fejlődése Magyarországon. Szeged: U. Szeged Kiadó

Nagy H. (2005): Kkv-k Magyarországon. www.rgvi.gtk.szie. hu/upload_files/Kkv_Mo.ppt (letöltés: 2011. márc 20.)
Némethné Pál K. (2010): Hol szökellnek a magyar gazellák? A dinamikusan növekvő kis- és középvállalatok néhány jellemzője. Vezetéstudomány, 4., p. 32-44. http:// www.gki.hu/sites/default/files/users/admin/nemethne_ gazellak.pdf

NKTH (2009): OECD Innovációpolitikai országtanulmányok. Magyarország. www.nih.gov.hu/...tanulmanyok/oecdinnovaciopolitikai-090831 (letöltés: 2012. április 20.)

Palócz É. (2010): Hallgat a felszín - fecseg a mély. Egy elhanyagolt szegmens a gyorsan növekvő KKV. Agyorsan növekvő magyar kis- és középvállalatok a gazdaság motorjai. Közgazdasági Szemle, LVII. évf., 2010. április, p. 354-370. http://epa.oszk.hu/00000/00017/00169/ pdf/04papanek.pdf (letöltés: 2012. március 20.)

Román Z. (2006a): Akis-és középvállalatokés a vállalkozások statisztikai helyzete. Gazdaság és Statisztika (GÉS), $17.56,2$, p. 37-53.

Román Z. (2006b): A kis- és középvállalatok és a vállalkozási készség. KSH http://tudasbazis.org.hu/doktar/makro gazdasag/kkv_ksh.pdf (letöltés: 2012. március 28.)

Sasvári P. (2008): Az információs és kommunikációs

2. ábra
A hazai kkv-kutatások vizsgálati szempontjai

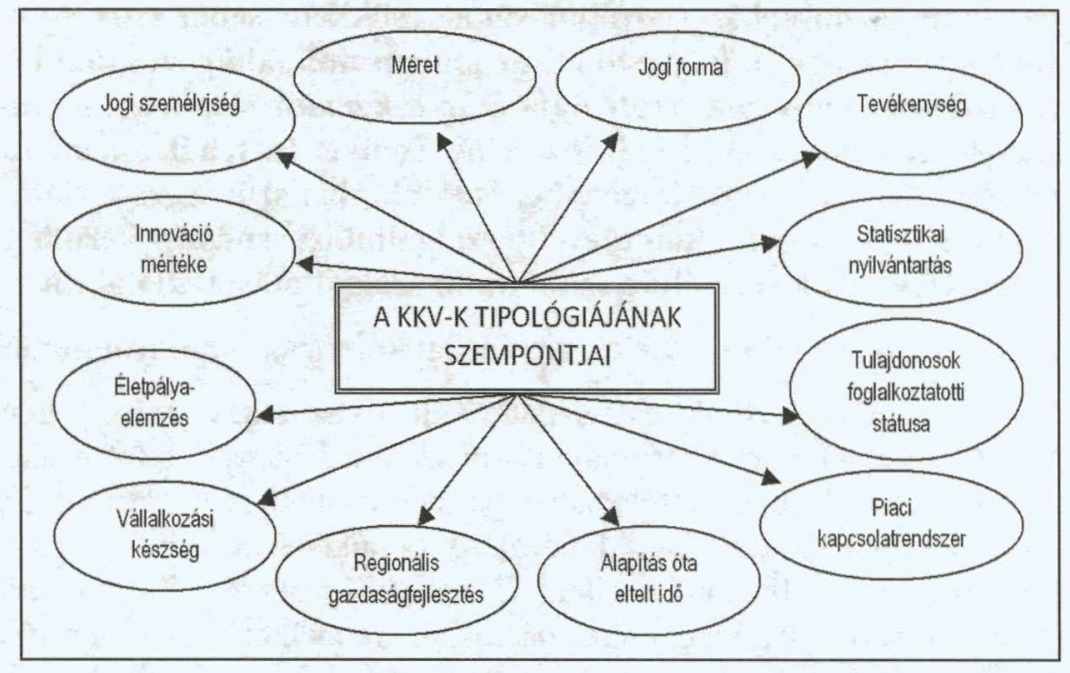

Forrás: saját szerkesztés, 2012

technológia fejlettségének empirikus vizsgálata. $\mathrm{PhD}$ értekezés. Miskolci Egyetem. http://mizar.mab.hu/odt111003/index.php?menuid=193\&vid=1581 (letöltés: 2011. október 20.)

Török Á. (1997): Az EU-hoz való közeledés várható hatásai a magyar kis- és középvállalatokra - a vállalkozások munkamegosztási szerepe. (Vitaindító a CIPE 1997. június 27-i konferenciájára). http://www.cipe.hu/publication_ roundtable8.asp (letöltés: 2005. augusztus 27.)

Vállalkozások demográfiája 1999-2003. (2006) Bp.: KSH

A vállalkozások teljesítménye (2004) Budapest: GKM

Vecsenyi J. (1999): Vállalkozási szervezetek és stratégiák. Budapest: AulaVecsenyi J. (2003): Vállalkozás - Az ötlettól az újrakezdésig. Budapest: Aula 